\title{
Belgeo
}

Revue belge de géographie

\section{Residential satisfaction and mobility behaviour among the young: insights from the post-Soviet city of Riga}

Wohnzufriedenheit und Mobilitätsverhalten zwischen der Jugend: Einsichten aus der Post-Sowietischen Stadt Riga

Jānis Krūmiṇš, Guido Sechi and Māris Bērziṇš

\section{(2) OpenEdition}

\section{Journals}

Electronic version

URL: http://journals.openedition.org/belgeo/28347

DOI: $10.4000 /$ belgeo.28347

ISSN: 2294-9135

\section{Publisher:}

National Committee of Geography of Belgium, Société Royale Belge de Géographie

\section{Electronic reference}

Jānis Krūminšš, Guido Sechi and Māris Bērzinšs, « Residential satisfaction and mobility behaviour among the young: insights from the post-Soviet city of Riga », Belgeo [Online], 3 | 2018, Online since 15 November 2018, connection on 20 April 2019. URL : http://journals.openedition.org/belgeo/28347 : DOI : 10.4000/belgeo.28347

This text was automatically generated on 20 April 2019.

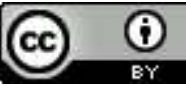

Belgeo est mis à disposition selon les termes de la licence Creative Commons Attribution 4.0 International. 


\section{Residential satisfaction and mobility behaviour among the young: insights from the post-Soviet city of Riga}

Wohnzufriedenheit und Mobilitätsverhalten zwischen der Jugend: Einsichten aus der Post-Sowietischen Stadt Riga

Jānis Krūmiṇš, Guido Sechi and Māris Bērziṇš

This study was supported by the Latvian Council of Science through the National Research Program 5.2. "Economic Transformation, Smart Growth, Governance and Legal Framework for the State and Society for Sustainable Development - a New Approach to the Creation of a Sustainable Learning Community (EKOSOC-LV) - Project 5.2.4 "Renewal of society through reducing the risk of depopulation, through demographic development and strengthening links with the diaspora for the transformation of the Latvian economy").

\section{Introduction}

Residential satisfaction - a subject of research in diverse areas of social and regional science - can be defined as the match between an individual's ideal environment and the objective and subjective characteristics of her / his actual environment (Huang et al. 2015; Sahraoui et al., 2016). It is considered a relevant component of life quality (Huang et al., 2015). Determinants of residential satisfaction are very complex and findings in this domain are not conclusive. Housing characteristics, neighbourhood environment and quality, household type, family characteristics and socio-demographic features, migration behaviour have been found to correlate significantly with residential satisfaction (Mohit, Adel, 2014; Huang et al., 2015; Lin, Li, 2017). The relationship between residential satisfaction and life and everyday mobility is particularly challenging and, in a certain sense, not fully explored. As for the former, residential mobility is considered 
both as a consequence of residential satisfaction and as a process which allows to improve it (Spackova et al., 2016). As for everyday mobility and its modes, they are related to neighbourhood satisfaction by affecting the perception of distance from work, school, shops etc. (Mohit, Adel, 2014).

2 Literature on residential satisfaction has developed in different directions in European and US studies, the former being more focused on differences between rental and ownership, the latter on gender, ethnicity and age differences (Pelin Sarioglu-Erdogdu, 2015).

3 Age-focused residential satisfaction literature has generally focused on the elderly, seen as particularly vulnerable to changes in the physical, functional and social aspects of their living environment and more dependent from such environment due to retirement and lower mobility (Temelova, Slezakova, 2014; Zhang, Zhang, 2017). On the other hand, younger residents - generally considered as more mobile and less attached to their residence place - are commonly overlooked in residential satisfaction studies, with the partial exception of students in university dormitories, whose satisfaction is generally found to be mostly affected by housing quality and social factors (Ning, Chen, 2016).

Residential satisfaction in the specific context of Central-Eastern Europe and former USSR is a relevant issue, due to the substantial physical and social transformation of former socialist countries in the last decades, but it tends to be overlooked in favour of strong emphasis on macro-scale processes (Kahrik et al., 2016). A rather developed micro-level analysis thread focuses on the social transformation and reputation of neighbourhoods in post-socialist cities (see e.g. Gentile, 2016). Among the few studies on residential satisfaction in the CEE, Hanak et al. (2015) find neighbourhood quality perception and logistics to be significant predictors among residents of the three main cities in Czech Republic. Herfert et al. (2013) investigate types of residential satisfaction and residential mobility, and their interrelations, in large scale housing estates of five large post-socialist European cities.

\section{Theoretical model}

In agreement with the most relevant literature, we hypothesize that residential satisfaction is affected by both subjective perceptions and objective characteristics of the housing and neighbourhood; family chracteristics; and life mobility (length of residence). Next to it, we incorporate predictors related to everyday mobility and modes of transport, which are generally neglected in quantitative modeling of residential satisfaction. Socio-demographic variables (household income, gender, educational level) are also included in the model as predictors.

\section{Study context}

6 Riga is the largest city in Latvia, and home to 641,423 (2017) inhabitants that is approximately one third of country's nearly 2 million population. There are several historical layers that define the contemporary urban structure of Riga. Thus, the city has evolved in three major phases, and its socio-spatial structure consists of three major urban zones, as it could be found in a great majority of cities in Central and Eastern Europe (e.g. Sykora, 2009; Kovacs, Herfert, 2012). 
7 The first layer, the historical core of inner-city or Old Town was formed since the $13^{\text {th }}$ century and nowadays its medieval core lies in the very central location among the other inner-city neighbourhoods (Figure 1). The second layer started its formation after the World War II, when Latvia was annexed by the Soviet Union. In following decades, the construction of large-scale panel housing estates started in order to establish an egalitarian Soviet society by settling people from different socio-economic categories in these new neighbourhoods. However, despite the fact that under the central planning system, the state sought to ensure satisfactory and equal living standards for all, previous studies have found significant levels of residential differentiation (French, Hamilton, 1979; Kornai, 1992; Enyedi, 1998). This can be mainly explained with massive in-migration flows from other states of the Soviet Union. These Russian-speaking immigrants usually received preferred conditions with new apartments allocated in the newly built largescale housing estates (Kulu, 2003; Gentile, Tammaru 2006). Likewise, in neighbouring Tallinn the quality of housing and its residential attractiveness in Riga is largely determined by the interplay of historical legacies of housing construction and geographical location within the particular city. Thus, the quality of dwellings in older and more distant or peripheral large-scale panel housing estates has significantly deteriorated over time (Kahrik, Tammaru, 2010).

Since the restoration of independence in 1991, political and economic restructuring took place, and Riga started to lose population due to negative demographic rates and by outmigration. Despite the fact that Riga lost thousands of Russian speaking out-migrants during 1990s, many still opted to stay. According to national statistics, the share of ethnic minorities even today constitutes more than half of city's population (CSB, 2017), thus competing with Latvians for better conditions in a free market oriented economy. The studies have confirmed that the members of the Russian-speaking minority in Latvia have adjusted worse to economic restructuring and suffered more from employment losses in different industrial sectors in which they were overrepresented (Aasland, 2002; Lindermann, 2013; Muiznieks et al., 2013). Nevertheless, today slightly more than 75 percent of the inhabitants of Riga live in Soviet-era mass housing areas or neighbourhoods dominated by this distinctive type of housing. According to 2011 Population Census, $55 \%$ of all residents living in Soviet mass housing were Russians, Belarussians or Ukrainians, while this share was considerably lower for Latvians (38.8\%). In contrast, the share of Latvians is slightly higher in the inner city and considerably higher in the outer city - the third layer of housing. This area mostly constitutes of newly built and expensive apartments, and provides house to higher income groups of population, and had rapidly emerged through processes of suburbanization after 1991. 
Figure 1. Neighbourhoods divided by urban zones in Riga.

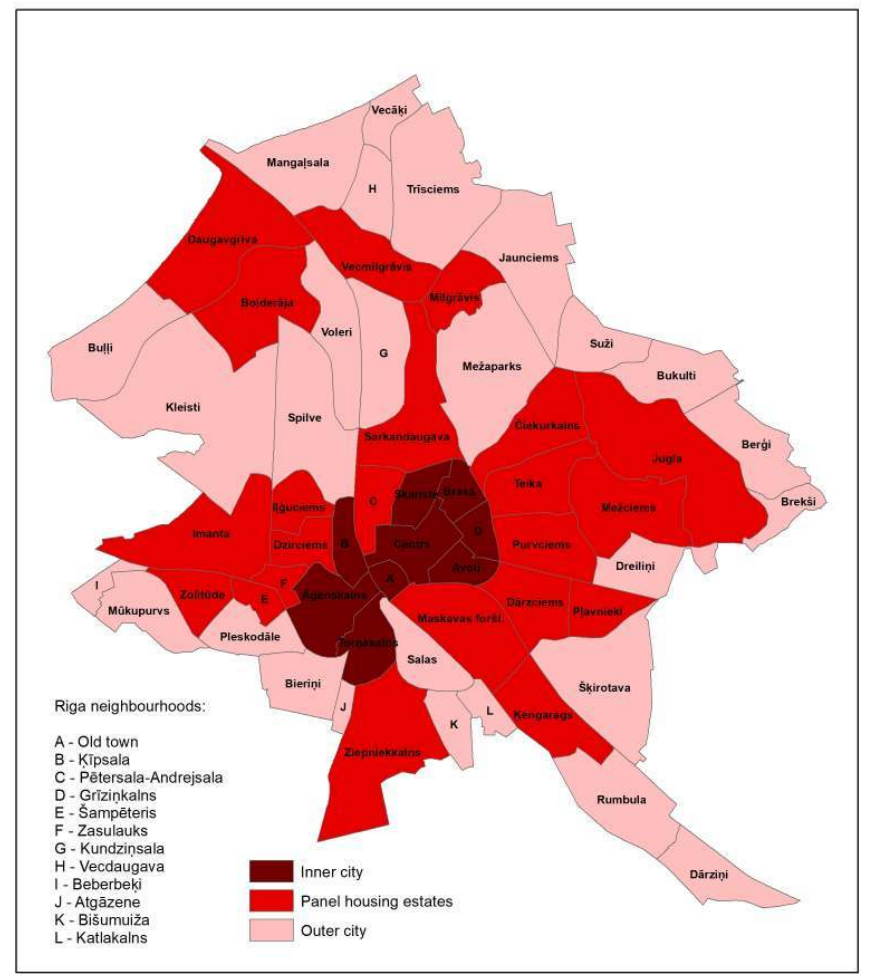

Source: authors' figure; Riga city council

Three urban zones highly differ not only by ethnic composition, but also by the age structure of residents. In 2011, the average age of residents of panel housing estates was 42.7 years, whereas the inhabitants of inner city (40.2) and outer city (39.6) were considerably younger. Several studies that examine post-socialist city metropolitan regions, reveal the difference in sociodemographic and socioeconomic characteristics between the residents of core city and suburban regions (Kahrik, Tammaru, 2008; Spackova, Ourednicek, 2011). While the core city is more attractive to younger people, families with children are more represented among suburbanites. In such case, the inner city of Riga can be functionally associated with the former, whereas the outer city is considered as mostly suburban area.

Statistics prove that the residents of inner and outer urban zone are younger than those of panel housing estates built during the Soviet time. In 2016, the share of 15-34 years old residents in neighbourhoods varied from $21 \%$ to $38 \%$ (Figure 2). For 24 out of 58 neighbourhoods the share of young adults exceeds $25 \%$. 
Figure 2. Share of young residents (15-34 years old) by neighbourhoods of Riga in 2016.

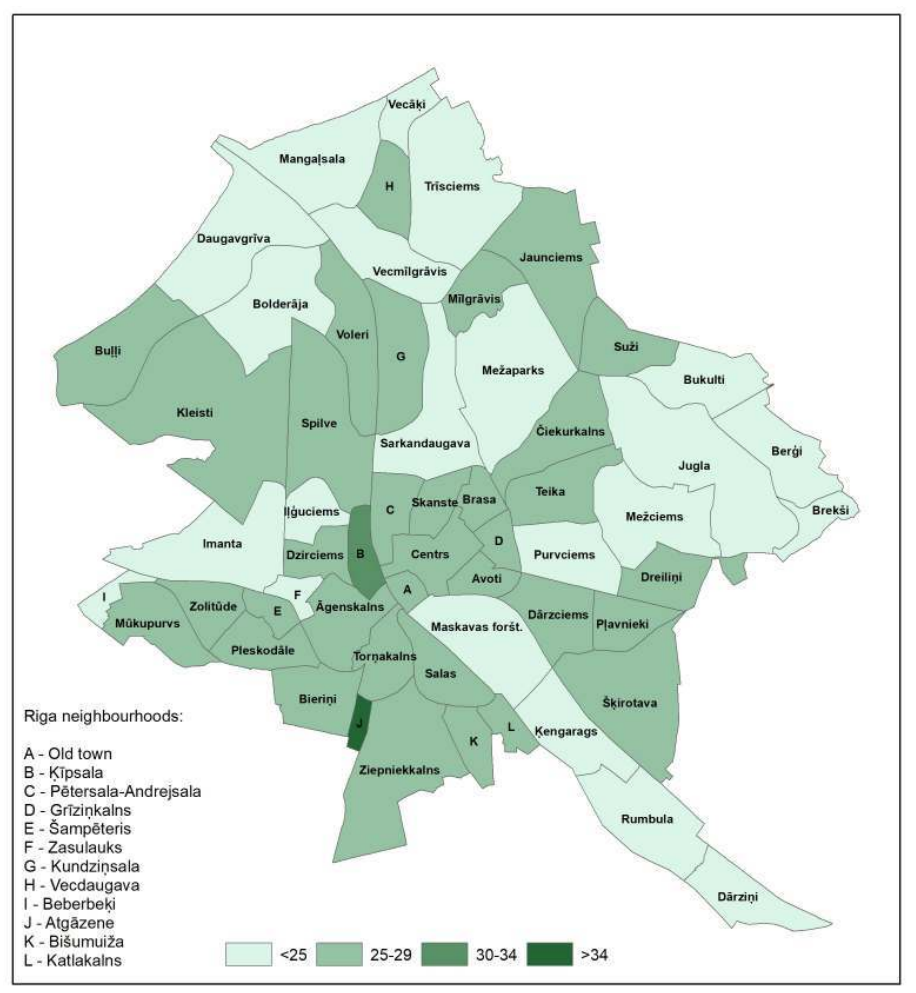

Authors' analysis of data derived from Central Statistics Bureau of Latvia

\section{Data and methodology}

11 The empirical analysis was based on panel survey data collected in 2015 and including 2,043 respondents resident in Riga, in the 15-74 age range. Out of the overall sample, 703 respondents are in the 15-34 years age range.

The analysis has been based on multiple linear regression.

The dependent variable (residential satisfaction) is a metric scale built upon psychometric items measured on 4-point Likert scales, measuring satisfaction with the residential environment. The predictors include scales, metric, ordinal, dichotomous and categorical variables:

- Quality of lighting, quality of water infrastructure, quality of public transport and quality of roads are scales built upon psychometric items measured on 4-point Likert scales;

- Frequency of use of public transport, car, and bicycle, and attitude towards panel housing estates, are single items measured on 4-point Likert scales;

- Family size is a metric variable;

- Education level and household income are an ordinal variables (5 levels);

- Presence of children aged under 18 , life mobility, everyday commuting, type of housing and type of neighbourhood are dichotomous variables;

- Gender is categorical.

Exploratory factor analysis has been used as a supporting technique in order to create scales on the basis of psychometric items. 
Relevant descriptive statistics for the sample are listed in Tables 1 and 2. They are broken down by age groups (respondents aged 15-34 vs respondents aged over 34).

Table 1. Socio-demographic and socio-economic sample composition. Descriptive statistics.

\begin{tabular}{|c|c|c|c|}
\hline & $15-34$ & Over 34 & Total \\
\hline \multicolumn{4}{|l|}{ Gender } \\
\hline Males & $42.8 \%$ & $38.0 \%$ & $39.6 \%$ \\
\hline Females & $57.2 \%$ & $62.0 \%$ & $60.4 \%$ \\
\hline \multicolumn{4}{|l|}{ Education level } \\
\hline Primary & $10.2 \%$ & $3.7 \%$ & $6.0 \%$ \\
\hline Secondary & $57.9 \%$ & $65.1 \%$ & $62.6 \%$ \\
\hline Tertiary & $31.9 \%$ & $31.2 \%$ & $31.4 \%$ \\
\hline \multicolumn{4}{|l|}{ Family size } \\
\hline One person & $10.5 \%$ & $22.6 \%$ & $18.5 \%$ \\
\hline Two persons & $25.1 \%$ & $38.8 \%$ & $34.0 \%$ \\
\hline Three persons & $37.4 \%$ & $19.4 \%$ & $25.7 \%$ \\
\hline Four persons & $20.5 \%$ & $13.7 \%$ & $15.9 \%$ \\
\hline Five persons (or more) & $6.5 \%$ & $5.5 \%$ & $5.9 \%$ \\
\hline \multicolumn{4}{|c|}{ School age (0-18) children in household } \\
\hline Yes & $49.9 \%$ & $29.3 \%$ & $36.4 \%$ \\
\hline No & $50.1 \%$ & $70.7 \%$ & $63.6 \%$ \\
\hline \multicolumn{4}{|c|}{ Household income (per person) } \\
\hline Low & $11.7 \%$ & $16.2 \%$ & $14.7 \%$ \\
\hline Moderately low & $15.2 \%$ & $29.9 \%$ & $24.8 \%$ \\
\hline Average & $12.7 \%$ & $17.2 \%$ & $15.6 \%$ \\
\hline Moderately high & $13.4 \%$ & $9.8 \%$ & $11.1 \%$ \\
\hline High & $16.1 \%$ & $12.4 \%$ & $13.7 \%$ \\
\hline Does not know & $30.9 \%$ & $14.5 \%$ & $20.1 \%$ \\
\hline
\end{tabular}




\begin{tabular}{|c|c|c|c|}
\hline \multicolumn{4}{|l|}{ Internal migration } \\
\hline Mobile respondents & $45.1 \%$ & $50.8 \%$ & $48.8 \%$ \\
\hline Non-mobile respondents & $54.9 \%$ & $49.2 \%$ & $51.2 \%$ \\
\hline \multicolumn{4}{|l|}{ Commuting } \\
\hline Urban commuters & $29.4 \%$ & $32.6 \%$ & $31.3 \%$ \\
\hline Non commuters & $70.6 \%$ & $67.4 \%$ & $68.7 \%$ \\
\hline \multicolumn{4}{|l|}{ Type of dwelling } \\
\hline Private housing & $8.4 \%$ & $8.4 \%$ & $8.4 \%$ \\
\hline Flat & $91.6 \%$ & $91.6 \%$ & $91.6 \%$ \\
\hline \multicolumn{4}{|l|}{ Use of public transport } \\
\hline Have not used during the last year & $8.2 \%$ & $6.7 \%$ & $7.2 \%$ \\
\hline Less than once in a week & $21.1 \%$ & $16.7 \%$ & $18.2 \%$ \\
\hline At least once a week & $21.6 \%$ & $31.4 \%$ & $28.0 \%$ \\
\hline Every or almost every day & $49.1 \%$ & $45.2 \%$ & $46.5 \%$ \\
\hline \multicolumn{4}{|l|}{ Use of private transport } \\
\hline Have not used during the last year & $31.2 \%$ & $44.6 \%$ & $39.9 \%$ \\
\hline Less than once in a week & $17.9 \%$ & $13.9 \%$ & $15.3 \%$ \\
\hline At least once a week & $23.0 \%$ & $18.7 \%$ & $20.2 \%$ \\
\hline Every or almost every day & $27.9 \%$ & $22.9 \%$ & $24.6 \%$ \\
\hline \multicolumn{4}{|l|}{ Use of bicycle } \\
\hline Have not used during the last year & $48.5 \%$ & $74.4 \%$ & $65.5 \%$ \\
\hline Less than once in a week & $19.0 \%$ & $11.9 \%$ & $14.4 \%$ \\
\hline At least once a week & $20.2 \%$ & $10.9 \%$ & $14.0 \%$ \\
\hline Every or almost every day & $12.4 \%$ & $2.8 \%$ & $6.1 \%$ \\
\hline
\end{tabular}

16 Overall, compared to elder ones, younger residents in our sample, as an average, live in larger households with 3 or more persons in family. Elderly, in contrast, are more prone to have 1 or 2 persons per household. More persons in family mean that younger 
respondents also have higher share of those who have school aged children in their household.

Younger respondents in our sample use means of private or bicycle transport more frequently than elderly ones. Both groups are equally mobile when using public transport. Higher share of young respondents uses public transport every or almost every day, compared to the elderly. In contrast, those respondents who are older than 34 years, are more prone to use public transport once or twice in a week. Overall, younger respondents are more mobile by the means of use of public, private and bicycle transport. Interestingly, younger respondents are slightly less mobile by the means of mobility. $45.1 \%$ of younger respondents have changed their place of residence since 2007, whereas for the elderly this share exceeds the non-mobile and reaches $50.8 \%$. Younger respondents are also less inclined to have a working place in another neighbourhood. In this case, $29.4 \%$ of $15-34$ years old respondents can be considered as urban commuters, while for the elderly this share is slightly higher (32.6\%).

Table 2. Attitudinal variables. Mean values.

\begin{tabular}{|l|l|l|l|}
\hline & $\mathbf{1 5 - 3 4}$ & Over 34 & Range \\
\hline Quality of lighting & 9.24 & 9.24 & $3-12$ \\
\hline Water quality & 6.24 & 6.22 & $2-8$ \\
\hline Quality of public transport & 3.84 & 3.75 & $2-8$ \\
\hline Quality of roads & 9.24 & 9.15 & $4-16$ \\
\hline Attitude towards Soviet mass housing & 2.99 & 3.03 & $1-4$ \\
\hline
\end{tabular}

Both groups equally assess the quality of lighting in their neighbourhood, while younger respondents have slightly higher evaluation of water quality, and the quality of public transport, and the road infrastructure. The elderly, in contrast, have slightly better attitude towards Soviet mass housing.

\section{Regression analysis: results}

The model for the cohort of respondents aged below 35 has a very high overall significance and a moderate goodness-of-fit and explanatory power.

Residential satisfaction is positively affected by positive assessment of neighbourhood infrastructure (lighting and, to a much lesser extent, water), by the presence of children aged below 18 in the household, and life mobility. It is negatively affected by positive assessment of road infrastructure in the city; frequency of car and public transport use; family size; and, to a lesser extent, living in a flat. Assessment of public transport, household income, commuting habits, bicycle use, type of neighbourhood, type of dwelling, gender and education are non-significant factors. 
Table 3. Linear regression: residential satisfaction. Respondents aged 15-34.

\begin{tabular}{|c|c|}
\hline Independent variable & Standardized coefficient (Beta) \\
\hline Scale: quality of lighting & $.172^{* * *}$ \\
\hline Scale: quality of water infrastructure & $.112^{*}$ \\
\hline Scale: quality of public transport & -.086 \\
\hline Scale: quality of roads & $-.236 * * *$ \\
\hline Family size & $-.117^{*}$ \\
\hline Household income & -.086 \\
\hline Children under 18: yes & $.147^{* *}$ \\
\hline Life mobility:yes & $.098^{*}$ \\
\hline Everyday commuting:yes & -.014 \\
\hline Frequency of public transport use & $-.137^{* *}$ \\
\hline Frequency of car use & $-.164^{* * *}$ \\
\hline Frequency of bicycle use & -.027 \\
\hline Type of housing: flat & $-.103^{*}$ \\
\hline Type of neighbourhood: panel housing estate & -.016 \\
\hline Attitude towards dwelling & .082 \\
\hline Gender: female & .031 \\
\hline Education level & .053 \\
\hline Constant & $7.038^{* * *}$ \\
\hline Sample size & 703 \\
\hline F(sig.) & $6.799(.000)$ \\
\hline R-square & .275 \\
\hline Adjusted R-square & .235 \\
\hline
\end{tabular}

The model for the cohort of respondents aged 35 and above (Table 4) has a very high overall significance and a moderate goodness-of-fit and explanatory power. Residential satisfaction is positively affected by positive assessment of neighbourhood infrastructure (lighting and water) and positive assessment of panel housing estate. It is 
negatively affected by positive assessment of road infrastructure in the city and family size.

Assessment of public transport, household income, presence of children aged below 18 in the household, life mobility, commuting habits, public transport, car and bicycle use, type of neighbourhood, gender and education are non-significant factors.

Table 4. Linear regression: residential satisfaction. Respondents aged 35-74.

\begin{tabular}{|c|c|}
\hline Independent variable & Standardized coefficient (Beta) \\
\hline Scale: quality of lighting & $.211^{* * *}$ \\
\hline Scale: quality of water infrastructure & $.135^{* * *}$ \\
\hline Scale: quality of public transport & -.046 \\
\hline Scale: quality of roads & $-.211^{* * *}$ \\
\hline Family size & $-.132^{* *}$ \\
\hline Household income & -.077 \\
\hline Children under 18: yes & -.017 \\
\hline Life mobility:yes & -.054 \\
\hline Everyday commuting:yes & .052 \\
\hline Frequency of public transport use & .054 \\
\hline Frequency of car use & .038 \\
\hline Frequency of bicycle use & .027 \\
\hline Type of housing: flat & -.040 \\
\hline Type of neighbourhood: panel housing estate & -.001 \\
\hline Attitude towards dwelling & $.077^{*}$ \\
\hline Gender: female & .031 \\
\hline Education level & .053 \\
\hline Constant & $5.484^{* * *}$ \\
\hline Sample size & 1340 \\
\hline F(sig.) & $9.325(.000)$ \\
\hline R-square & .257 \\
\hline Adjusted R-square & .230 \\
\hline
\end{tabular}




\section{Discussion of results}

Overall, results show that residential satisfaction among younger Riga residents is affected by everyday mobility modes, neighbourhood quality perception, family characteristics, and, to a much lesser extent, household characteristics and length of residence. The considered socio-demographic factors, and housing characteristics, have been found to be non-significant.

Although commuting behaviour is not in itself a significant predictor, the strongest predictors in the model relate to transport use and infrastructure, showing a relevant impact of everyday mobility on residential satisfaction.

When comparing results for younger Riga residents and elder ones, some relevant differences have been found. Among the selected categories of predictors, the most striking difference relates to the impact of mobility (transport) modes, which is found to be negligible among elder residents. Minor differences are related to household and family characteristics and length of residence (life mobility).

\section{BIBLIOGRAPHY}

AASLAND A. (2002), "Citizenship status and social exclusion in Estonia and Latvia”, Journal of Baltic Studies, 33, 1, pp. 57-77.

CSB (2017), Territorial (experimental) statistics, Neighbourhoods of Riga, Central Statistics Bureau of Latvia, http://data.csb.gov.lv/pxweb/lv/Sociala/Sociala__ikgad_iedz__riga/?

tablelist=true\&rxid=cdcb978c-22b0-416a-aacc-aa650d3e2ce0.

ENYEDI G. (1998), “Transformation in Central European Postsocialist Cities” in ENYEDI G. (ed.), Social Change and Urban Restructuring in Central Europe, Budapest, Akademiai Kiado, pp. 9-34.

FRENCH R., HAMILTON F. (1979), The Socialist City. Spatial Structure and Urban Policy, Chichester, John Wiley.

GENTILE M. (2016), "Neighbourhood reputation in the Soviet city and beyond: Disassembling the geography of prestige in Ust'-Kamenogorsk, Kazakhstan”, European Urban and Regional Studies, 23, 4, pp. 697-715.

GENTILE M., TAMMARU T. (2006), “Housing and ethnicity in the Post-Soviet city: Ust'Kamenogorsk, Kazakhstan”, Urban Studies, 43, 10, pp. 1757-1778.

HANAK T., MAROVIC I. \& AIGEL P. (2015), “Perception of Residential Environment in Cities: a Comparative Study", Procedia Engineering, 117, pp. 495-501.

HERFERT G., NEUGEBAUER C.S. \& SMIGIEL C. (2013), “Living in Residential Satisfaction? Insights from Large-Scale Housing Estates in Central and Eastern Europe", Tijdschrift voor economische en sociale geografie, 104, pp. 57-74. 
HUANG Z., DU X. \& YU X. (2015), “Home ownership and residential satisfaction: Evidence from Hangzhou, China", Habitat International, 49, pp. 74-83.

KAHRIK A., TAMMARU T. (2008), "Population composition in new suburban settlement of the Tallinn metropolitan area”, Urban Studies, 45, pp. 1055-1078.

KAHRIK A., TAMMARU T. (2010), “Soviet prefabricated panel housing estates: Areas of continued social mix or decline? The case of Tallinn", Housing Studies, 25, 2, pp. 201-219.

KAHRIK A., TEMELOVA J., KADARIK K. \& KUBES J. (2016), “What attracts people to inner city areas? The cases of two post-socialist cities in Estonia and the Czech Republic", Urban Studies, 53, 2, pp. 355-372.

KORNAI J. (1992), The socialist system: The political economy of communism, Oxford University Press.

KOVACS Z., HERFERT G. (2012), “Development pathways of large housing estates in post-socialist cities: An international comparison", Housing Studies, 27, 3, pp. 324-342.

KULU H. (2003), "Housing Differences in the Late Soviet City: The Case of Tartu, Estonia", International Journal of Urban and Regional Research, 27, 4, pp. 897-911.

LIN S., LI Z. (2017), “Residential satisfaction of migrants in Wenzhou, an 'ordinary city' of China”, Habitat International, 66, pp. 76-85.

LINDEMANN K. (2013), “The school performance of the Russian-speaking minority in linguistically divided educational systems: A comparison of Estonia and Latvia", in Integration and Inequality in Educational Institutions, Springer Netherlands, pp. 45-69.

MOHIT M.A., ADEL MAHFOUD M.A. (2014), "Residential satisfaction - concepts, theories and empirical studies", Planning Malaysia - Journal of Malaysian Institute of Planners, 3, pp. 47-66.

MUIZNIEKS N., ROZENVALDS J. \& BIRKA I. (2013), "Ethnicity and social cohesion in the postSoviet Baltic states", Patterns of Prejudice, 47, 3, pp. 288-308.

NING Y., CHEN J. (2016), “Improving Residential Satisfaction of University Dormitories through Post-Occupancy Evaluation in China: A Socio-Technical System Approach", Sustainability, 1050, 8, pp. 1-17.

PELIN SARIOGLU-ERDOGDU G. (2015), "Well-being of renters in Ankara: An empirical analysis”, Habitat International, 48, pp. 30-37.

SPACKOVA P., OUREDNICEK M. (2011), “Spinning the web: New social contacts of Prague's suburbanites", Cities, 29, pp. 341-349.

SPACKOVA P., DVORAKOVA N. \& TOBRMANOVA M. (2017), "Residential Satisfaction and Intention to Move: The Case of Prague's New Suburbanites”, Geografiska Annaler: Series B, Human Geography, 98, 4, pp. 331-348.

SYKORA L. (2009), "New socio-spatial formations: Places of residential segregation and separation in Czechia", Tijdschrift voor Economische en Sociale Geografie, 100, 4, pp. 417-435.

TEMELOVA J., SLEZAKOVA A. (2014), “The changing environment and neighbourhood satisfaction in socialist high-rise panel housing estates: The time-comparative perceptions of elderly residents in Prague", Cities, 37, pp. 82-91.

ZHANG Z., ZHANG J. (2017), "Perceived residential environment of neighborhood and subjective well-being among the elderly in China: A mediating role of sense of community", Journal of Environmental Psychology, 51, pp. 82-94. 


\section{ABSTRACTS}

Urban residential areas in the former Soviet Union and Central Eastern Europe have experienced radical demographic and socioeconomic changes, with relevant consequences for residents. Although many studies have addressed post-socialist urban change at the macro level, little is known about individuals' residential satisfaction. Besides, in this domain, two gaps must be acknowledged. First, most studies on residential satisfaction tend to focus on 'static' predictors, overlooking the interrelation of residential satisfaction with mobility behaviour, in spite of it being widely acknowledged in literature. Second, the analysis of residential satisfaction among specific socio-demographic groups tends to overlook younger residents in favour of groups which are considered to be more vulnerable.

The aim of this study is to investigate how both mobility and static factors affect young individuals' assessment of residential satisfaction. The research is based on 2015 panel survey data. The survey sample consists of around 700 permanent residents of Riga in the 15-34 age range. The findings suggest that residential satisfaction is significantly influenced, among other factors, by aspects of everyday mobility. In particular, our results highlight that transport modes and habits significantly affect residential satisfaction among younger residents, whereas they are negligible among elder ones.

Die städtischen Wohngebiete der ehemaligen UdSSR und Zentral-Osteuropa erfuhren radikale, demographische und sozioökonomische Veränderungen, welche relevante Folgen für die Einwohner zur Folge hatten. Obwohl viele Studien post-sozialistische und urbane Veränderungen auf der Makroebene addressierten, blieb die Wohnzufriedenheit außer Betracht. Desweiteren sollten in diesem Fall zwei Mängel erwähnt werden. Erstens: die meisten Studien zur Wohnzufriedenheit konzentrierten sich auf feststehenden Prädiktoren und übersahen den Zusammenhang zwischen der Wohnzufriedenheit und der Mobilität, trotz ihrer Anerkennung in der Literatur. Zweitens: die Analyse der Wohnzufriedenheit zwischen spezifischen, soziodemographischen Gruppen tendierte dazu, jüngere Einwohner zu übersehen, zugunsten von anderen Gruppen, die als anfälliger und gefährdeter angesehen wurden.

Das Ziel der vorliegenden Arbeit lag darin, herauszufinden, wie Mobilität und statische Faktoren die Bewertung der Wohnzufriedenheit der Jugend beeinflussten. Die Forschung basierte auf Daten einer Panel-Umfrage aus dem Jahr 2015. Die Unterstichprobe der Umfrage bestand aus ungefähr 700 dauerhaften Einwohnern der Stadt Riga im Alter von 15 bis 34 Jahren. Die Ergebnisse deuteten darauf hin, dass die Wohnzufriedenheit erheblich von, unter anderem, Aspekten täglicher Mobilität beeinflusst wurde. Vor allem heben diese Ergebnisse hervor, dass die Transportarten und die Transportgewohnheiten, die Wohnzufriedenheit der Jugend bedeutend beeinflussten, während diese Faktoren für die älteren Einwohner unerheblich sind.

\section{INDEX}

Mots-clés: residential satisfaction, mobility, younger residents, post-socialist cities, Riga, Latvia Schlüsselwörter: Wohnzufriedenheit, Mobilität, Jugend, Post-sozialistische Städte, Riga, Lettland 


\section{AUTHORS}

\section{JĀNIS KRŪMINŠ}

University of Latvia, kruminsjanis3@gmail.com

\section{GUIDO SECHI}

University of Latvia, guidosechi78@gmail.com

\section{MĀRIS BĒRZIN̦Š}

University of Latvia, maris.berzins@lu.lv 